\title{
EFEKTIVITAS PROBLEM BASED LEARNING DAN PROBLEM SOLVING TERHADAP KEMAMPUAN BERPIKIR KRITIS SISWA KELAS V DALAM PEMBELAJARAN MATEMATIKA
}

\author{
Elva Pristy Afifah ${ }^{1}$, Wahyudi², Yohana Setiawan ${ }^{3}$ \\ 1, 2, 3 Universitas Kristen Satya Wacana \\ 292015035@student.uksw.edu ${ }^{1}$,yudhi@staff.uksw.edu ${ }^{2}$, \\ yohana.setiawan05@gmail.com ${ }^{3}$
}

\begin{abstract}
ABSTRAK
Penelitian ini memiliki tujuan untuk mengetahui perbedaan efektivitas model Problem Based Learning dan Problem Solving terhadap kemampuan berpikir kritis siswa kelas 5 pada pembelajaran matematika. Penelitian ini termasuk penelitian eksperimen semu. Sampel pada penelitian ini yaitu 23 siswa SDN Gedangdowo 02 dan 18 siswa SDN Soko. Keberhasilan penelitian ini dilihat berdasarkan hasil analisis uji N-Gain untuk mengetahui keefektifannya, eksperimen 1 yang menggunakan model Problem Based Learning dan kelas eksperimen 2 menggunakan model Problem Solving. Hasil uji N-Gain menunjukkan kelas eksperimen 1 sebesar 0,59 dan kelas eksperimen 2 sebesar 0,50. Berdasarkan hasil penelitian dikatakan $\mathrm{H}_{0}$ ditolak dan $\mathrm{H}_{\mathrm{a}}$ diterima. Kesimpulannya adalah terdapat peningkatan kemampuan berpikir kritis antara siswa kelas V SDN Gedangdowo 02 menggunakan model pembelajaran Problem Based Learning dengan siswa kelas V SDN Soko menggunakan model pembelajaran Problem Solving. Dari hasil penelitian merekomendasikan pembelajaran dengan model Problem Based Learning dapat meningkatkan kemampuan berpikir kritis siswa, sebaiknya dijadikan alternatif dalam kegiatan pembelajaran matematika pada materi volume bangun ruang kubus dan balok.
\end{abstract}

Kata kunci: berpikir kritis, problem based learning, problem solving,

\begin{abstract}
This study aims to determine the differences in the effectiveness of the Problem Based Learning and Problem Solving models on 5th grade students' critical thinking skills in mathematics learning. This research includes quasi-experimental research. The sample in this study were 23 students of SDN Gedangdowo 02 and 18 students of SDN Soko. The success of this study was seen based on the results of the N-Gain test to determine its effectiveness, experiment 1 using the Problem Based Learning model and experimental class 2 using the Problem Solving model. The results of the $\mathrm{N}$-Gain test show that the experimental class 1 is 0.59 and the
\end{abstract}




\section{Elva Pristy Afifah, Wahyudi, Yohana Setiawan}

experimental class 2 is 0.50 . So based on the results of the study it was said that $\mathrm{H}_{0}$ was rejected and $\mathrm{H}_{\mathrm{a}}$ was accepted. The conclusion is that there is an increase in critical thinking skills between fifth grade students of SDN Gedangdowo 02 using the Problem Based Learning learning model with fifth grade students of Soko Elementary School using the Problem Solving learning model. From the results of the study recommending learning with the Problem Based Learning model can improve students' critical thinking skills, it should be used as an alternative in mathematics learning activities on the volume material of building cubes and blocks.

Keywords: critical thinking, problem based learning, problem solving

\section{PENDAHULUAN}

Kurikulum yang berlaku di Indonesia sekarang ini adalah kurikulum 2013. Kurikulum 2013 mengarah pada pembelajaran yang berbasis tematik integratif. Pembelajaran tematik integratif merupakan pembelajaran yang menggunakan tema sebagai pemersatu kegiatan pembelajaran yang memadukan beberapa mata pelajaran sekaligus dalam satu kali tatap muka (Mawardi, 2013). Pembelajaran tematik integratif yaitu pembelajaran dengan pendekatan yang mengintegrasikan berbagai kompetensi dan berbagai mata pelajaran dalam tema (Rahmawati, 2015). Pembelajaran tematik integratif adalah pembelajaran yang terdiri dari berbagai muatan pelajaran yang digabungkan sehingga membentuk suatu tema. Pada tingkat sekolah dasar pembelajaran tematik kelas rendah semua muatan pelajaran menjadi satu tetapi untuk kelas tinggi pelajaran matematika dan agama terpisah dari muatan pelajaran yang lainnya.

Matematika adalah mata pelajaran yang wajib ada di setiap jenjang pendidikan mulai dari SD hingga SMA. Matematika adalah mata pelajaran yang sering digunakan dalam kehidupan sehari-hari. Bukan hanya di sekolah, tetapi setiap saat akan selalu berhubungan dengan matematika. Namun, bagi sebagian besar siswa matematika adalah mata pelajaran yang sulit dan merasa kurang tertarik terhadap mata pelajaran matematika. Hal ini bisa jadi disebabkan karena metode, pendekatan atau penggunaan model pembelajaran yang digunakan oleh guru kurang menarik minat belajar siswa terhapap pelajaran matematika.

Dalam peraturan Menteri Pendidikan Nasional Nomor 20 Tahun 2006 mengatur tentang Standart isi, bahwa pembelajaran matematika bertujuan supaya 
siswa memiliki kemampuan penalaran tinggi melalui latihan memecahkan masalah, membuat keputusan dan kesimpulan. Harapannya, pembelajaran seperti ini membuat siswa terlatih untuk berpikir kritis dalam menyelesaikan persoalanpersoalan tersebut. Pembelajaran matematika yang baik diharapkan siswa akan dapat memiliki kemampuan berpikir logis, analitis, sistematis, kritis, kreatif dan kemampuan untuk bekerjasama secara efektif sesuai dengan yang tercantum dalam Kurikulum 2013 (Permendikbud, 2013).

Berpikir kritis sama pengertiannya dengan berpikir konvergen yang berarti berpikir menuju satu arah yang benar atau satu jawaban yang paling tepat atau satu pemecahan dari suatu masalah. Dengan berpikir kritis dapat membantu siswa lebih aktif dalam proses pembelajaran (Slameto, 2010). Berpikir kritis adalah sebuah proses yang terarah jelas dengan menggunakan kegiatan mental seperti memecahkan masalah, mengambil keputusan, menganalisis asumsi, dan melakukan penelitian ilmiah (Jhonson, 2010). Berpikir kritis adalah proses mental untuk menganalisis informasi. Informasi didapat melalui pengamatan, pengalaman, komunikasi, dan membaca (Suryosubroto, 2009). Berdasarkan uraian tersebut maka berpikir kritis merupakan proses berpikir ke arah yang lebih detail atau lebih mendalam. Berpikir kritis menuntut siswa untuk lebih meningkatkan kemampuan menganalisa suatu masalah, menemukan penyelesaian masalah serta memberikan ide-ide baru yang bisa memberikan gambaran baru atas pemecahan suatu masalah.

Menciptakan proses belajar mengajar yang menyenangkan adalah sesuatu yang menjadi tantangan seorang pendidik agar dapat meningkatkan minat belajar siswa. Oleh karena itu, pendidik diharapkan untuk dapat menciptakan proses belajar mengajar yang inovatif dan menyenangkan tetapi tidak menghilangkan tujuan pembelajaran yang akan dicapai. Agar tujuan pembelajaran dapat tercapai maka perlu diciptakan proses belajar mengajar yang bermakna. Pembelajaran yang bermakna dapat diwujudkan apabila siswa terlibat langsung dalam proses kegiatan belajar mengajar, tidak hanya ceramah dan menghafal setiap materi tetapi peserta didik dapat menemukan bahkan memecahkan masalah. Dengan hal 
itu, maka dibutuhkan model pembelajaran yang dapat menciptakan kondisi pembelajaran yang bermakna.

Banyak para ahli yang menemukan model pembelajaran inovatif yang dapat memfasilitasi peserta didik untuk dapat terlibat langsung pada proses belajar mengajar. Salah satunya ialah model pembelajaran berbasis pemecahan masalah yaitu model Problem Based Learning. Model pembelajaran Problem Based Learning menurut (Pusdiklates, 2003) adalah suatu proses pembelajaran yang diawali dari masalah-masalah atau lingkungan belajar yang didalamnya menggunakan masalah untuk belajar. Dimana peserta didik dihadapkan pada suatu masalah dan nantinya peserta didik akan memecahkan masalah tersebut dan memperoleh pengetahuan baru. Problem Based Learning adalah pembelajaran yang melatih dan mengembangkan kemampuan untuk menyelesaikan masalah berorientasi pada masalah otentik dari kehidupan aktual siswa, untuk merangsang kemampuan tingkat tinggi (Slameto, 2015). Model pembelajaran Problem Based Learning model pembelajaran yang melatih ketrampilan peserta didik untuk menyelesaikan masalah dan mendapat pengetahuan yang baru, selain itu dengan model pembelajaran Problem Based Learning melatih peserta didik untuk berpikir tingkat tinggi.

Problem Solving adalah belajar memecahkan masalah, pada tingkat ini peserta didik memecahkan masalah, memberikan respon terhadap rangsangan yang menggambarkan situasi permasalahan yang terjadi, yang menggunakan berbagai kaidah yang telah dikuasainya (Arif dan Hidayat, 2016). Model pembelajaran Problem Solving adalah pembelajaran dengan memberi kesempatan kepada peserta didik untuk memecahkan masalah sesuai situasi realitas dalam kehidupan sehari-hari Lee dalam (Agustina dan Vahlia, 2016). Maka disimpulkan bahwa model pembelajaran Problem Solving adalah proses pembelajaran pemecahan masalah dengan kemampuan yang dimiliki oleh peserta didik, sehingga dapat melatih kemampuan berpikir tingkat tinggi. Selain itu peserta didik juga mendapatkan pengalaman langsung dari proses pembelajaran yang ada.

Model pembelajaran Problem Based Learing dan Problem Solving keduanya sama pembelajaran berbasis masalah atau pemecahan masalah. Langkah pembelajaran Problem Based Learning dan Problem Solving sama yaitu 
pemberian masalah dari guru. Sedangkan perbedaan dari keduanya yaitu terletak pada masalah yang dipecahkan atau diselesaikan. Pada Problem Solving masalah yang diberikan biasanya bukan masalah yang nyata seperti pada Problem Based Learning, dan cara penyelesaiannya juga berbeda. Pada Problem Solving masalah dapat diselesaikan hanya dengan diskusi saja, tetapi pada Problem Based Learning dibutuhkan penelitian mengenai masalah, sehingga penyelesaian yang diberikan benar-benar telah banyak melalui proses yang panjang.

Dalam penelitian ini penulis melakukan eksperimen tentang Model Pembelajaran Problem Based Learning dan Problem Solving untuk meningkatkan kemampuan berfikir kritis. Hal ini ditinjau karena keraguraguan penulis dalam penerapan kedua model tersebut untuk meningkatkan berpikir kritis siswa pada materi bangun ruang kubus dan balok yang sebagian besar siswa masih mendapatkan nilai dibawah rata-rata.

\section{METODE PENELITIAN}

\section{Jenis Penelitian}

Jenis penelitian ini adalah penelitian eksperimen menggunakan metode eksperimen kuasi dengan pola non-equivalent control group design. Penelitian menggunakan desain eksperimen non-equivalent control group design dapat menyelidiki pengaruh dari dua atau lebih variabel yang digunakan. Desain penelitian inidapat melihat perbedaan efektivas model pembelajaran Problem Based Learning dan model pembelajaran Problem Solving setelah diberikan perlakukan. Berikut gambaran mengenai design penelitian Non equivalent control group design menurut Johnson \& Christensen (2014).

Tabel 1. Desain Eksperimen (Non-equivalent Control Group Design)

\begin{tabular}{lccc}
\hline Group & Pretest & Perlakuan & Posttest \\
\hline Eksperimen & $O_{1}$ & $X_{1}$ & $O_{2}$ \\
Kontrol & $O_{3}$ & $X_{2}$ & $O_{4}$ \\
\hline
\end{tabular}

Keterangan:

$O_{1}$ : Pengukuran awal hasil belajar (pretest) pada kelas eksperimen 1

$\mathrm{O}_{3}$ : Pengukuran awal hasil belajar (pretest) pada kelas eksperimen 2 
$X_{1}$ : Perlakuan untuk kelompok eksperimen yaitu pembelajaran menggunakan model pembelajaran Problem Based Learning (PBL)

$X_{2}$ : Perlakuan untuk kelompok kontrol yaitu pembelajaran dengan menggunakan model pembelajaran Problem Solving

$\mathrm{O}_{2}$ : Pengukuran akhir hasil belajar (posttest) pada kelas eksperimen 1

$\mathrm{O}_{4}$ : Pengukuran akhir hasil belajar (posttest) pada kelas eksperimen 2

Tempat penelitian di Gugus Madukara, Kecamatan Jepon, Kabupaten Blora. Populasi dalam penelitian ini adalah siswa kelas V sebanyak 41 siswa, 23 siswa SDN Gedangdowo 02, dan 18 siswa SDN Soko. Materi pembelajaran yang digunakan ialah menyelesaikan masalah mengenai volume bangun ruang kubus dan balok.

Berikut merupakan langkah-langkah yang digunakan dalam penelitian ini: memberikan soal pretest kepada dua kelompok eksperimen. Hal ini bertujuan untuk memahami kemampuan awal yang dimiliki siswa sebelum diberi perlakuan. Pada kelompok Ekspeimen 1 diberikan perlakuan menggunakan model $P B L$ dan kelompok Eksperimen 2 menggunakan model PS. Setelah diberikan perlakuan yang berbeda, kedua kelompok diberikan soal posttest yang bertujuan untuk mengetahui pengaruh setelah diberi perlakuan antara kedua model pembelajaran tersebut.

\section{Teknik dan Instrumen Pengumpulan Data}

Teknik pengumpulan data menggunakan teknik tes dan non tes. Teknik tes digunakan untuk mengetahui kemampuan berpikir kritis siswa. Bentuk tes yang digunakan adalah berupa tes uraian. Teknik non tes yang digunakan adalah teknik observasi yang digunakan untuk melihat situasi/kondisi tempat penelitian akan dilakukan.

Disamping itu, juga terdapat langkah-langkah untuk mengumpulkan data diantaranya: menyusun kisi-kisi, menyusun instrumen penelitian, melakukan uji validitas dan reliabilitas, memberikan pretest, memberikan tindakan penelitian, memberikan posttest, dan yang terakhir yaitu menganalisis data.

\section{Teknik Analisis Data}

Analisis data dilakukan untuk hasil data yang berupa proses dan hasil. Proses yang dimaksud adalah pelaksanaan pembelajaran untuk kedua model yang 
digunakan. Analisis hasil digunakan untuk menganalisis hasil tes yang digunakan untuk melihat efektivitas masing-masing model.

Keefektifan model $P B L$ dan $P S$ terhadap kemampuan berpikir kritis siswa dilakukan uji beda rata-rata dengan menggunakan Independent Sample T-Test. Penggunaan data dalam uji beda rata-rata adalah data sesudah perlakuan atau posttest. Kemudian setelah memperoleh hasil dilakukan uji hipotesis yang memiliki kriteria keputusan $\mathrm{H}_{0}$ diterima apabila probabilitas $>0,05$ dan $\mathrm{H}_{\mathrm{a}}$ diterima jika probabilitas $<0,05$. Setelah mengetahui keefektifan dari kedua model terhadap kemampuan berpikir kritis siswa, kemudian dilakukan uji N-Gain untuk mengetahui kekuatan efektivitas dari kedua kelas eksperimen.

\section{HASIL PENELITIAN DAN PEMBAHASAN}

Berdasarkan hasil analisis deskriptif diperoleh data komparasi hasil pengukuran pretest dan posttest kemampuan berpikir kritis siswa yang disajikan sebagai berikut:

Tabel 2. Komparasi Hasil Pengukuran Kemampuan Berpikir Kritis Siswa

\begin{tabular}{cccc}
\hline \multirow{2}{*}{ Pengukuran } & \multicolumn{2}{c}{ Rata-rata Skor (mean) } & \multirow{2}{*}{ Selisih } \\
\cline { 2 - 3 } & Eksperimen 1 & Eksperimen 2 & \\
\hline Pretest & 64,22 & 61,94 & 2,28 \\
Posttest & 85,83 & 80,44 & 5,39 \\
\hline
\end{tabular}

Berdasarkan data komparasi rata-rata yang disajikan pada Tabel 2, ratarata skor pretest antara kelompok eksperimen 1 yang diberikan perlakuan $P B L$ dan kelompok eksperimen 2 yang diberi perlakuan $P S$ terdapat selisih sekitar 2,24. Sedangkan untuk rata-rata skor posttest antara kedua kelompok eksperimen terdapat selisih sebesar 5,36. Berikut diagram komparasi data kedua kelompok disajikan dalam Gambar 1.

Berdasarkan informasi Gambar 1, dapat diketahui adanya peningkatan pada kelompok eksperimen 1 yang menerapkan model PBL maupun kelompok eksperimen 2 dengan model PS. Dari hasil perolehan data penelitian selanjutnya dilaksanakan uji normalitas dan uji homogenitas sebagai uji persyaratan. Hasil uji normalitas dapat dilihat pada Tabel 3 sedangkan hasil uji homogenitas pada Tabel 4 dan 5. 


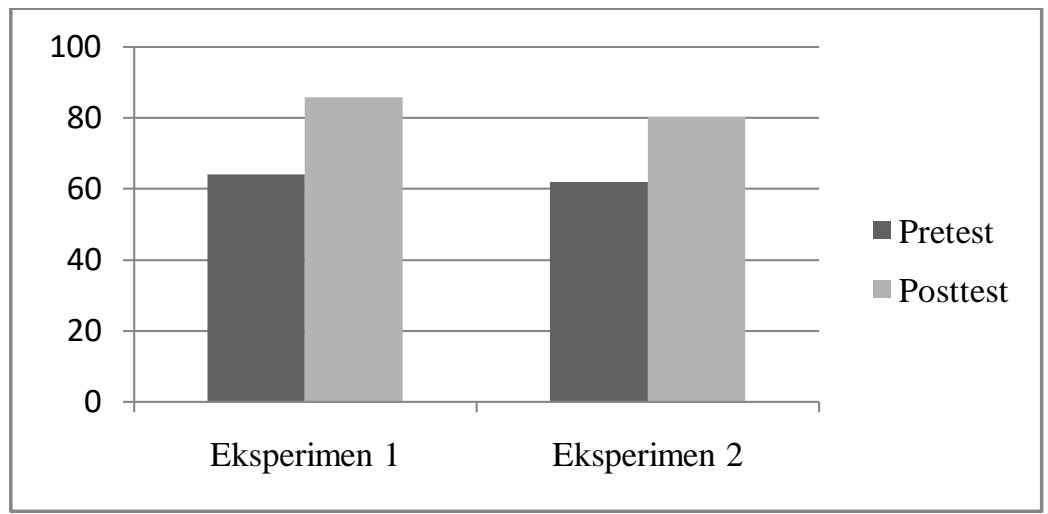

Gambar 1. Komparasi Data Kelompok Eksperimen

Tabel 3. Uji Normalitas Kelompok Eksperimen 1 dan Eksperimen 2

\begin{tabular}{llccc}
\hline & & \multicolumn{3}{c}{ Shapiro-Wilk } \\
\cline { 2 - 4 } & Kelas & Statistic & Df & Sig. \\
\hline Hasil Belajar Siswa & Pretest PBL &, 922 & 23 &, 073 \\
& Posttest PBL &, 931 & 23 &, 117 \\
& Pretest PS &, 850 & 18 &, 008 \\
& Posttest PS &, 948 & 18 &, 397 \\
\hline
\end{tabular}

Hasil uji normalitas pretest dan posttest dari kedua kelas eksperimen. Teknik yang digunakan dalam uji normalitas adalah Shapiro-Wilk dapat dikatakan berdistribusi normal jika hasil signifikan $>0,05$.

1. Tingkat signifikasi nilai pretest kelompok eksperimen 1 adalah 0,073 >0,05, artinya nilai berdistribusi normal.

2. Tingkat signifikasi nilai posttest kelompok eksperimen 1 adalah 0,117>0,05, artinya nilai berdistribusi normal.

3. Tingkat signifikasi nilai pretest kelompok eksperimen 2 adalah 0,008 $>0,05$, artinya nilai berdistribusi normal.

4. Tingkat signifikasi nilai pretest kelompok eksperimen 2 adalah 0,397 >0,05, artinya nilai berdistribusi normal.

Dari data diatas dapat diketahui perolehan hasil pretest dan posttest signifikan > 0,05 maka disimpulkan bahwa data memiliki berdistribusi normal.

Berdasarkan informasi Tabel 4 dan Tabel 5 diperoleh hasil uji homogenitas menggunakan metode Lavene's Test. Dengan memilih salah satu interprestasi statistik yang didasarkan pada rata-rata (Based on Mean). Pada Tabel 4 menunjukkan hasil uji homogenitas sebelum diberi perlakuan memperoleh nilai 
signifikasi 0,007 dimana $<0,05$ yang berarti kedua kelas sebelum diberi perlakuan tidak memiliki varian yang sama atau tidak homogen. Sedangkan pada Tabel 5 menunjukkan hasil uji homogenitas setelah diberi perlakuan memperoleh nilai signifikasi 0,802 dimana > 0,05 yang berarti kedua kelas sesudah diberi perlakuan memiliki varian yang berbeda atau homogen

Tabel 4. Uji Homogenitas Sebelum Perlakuan

\begin{tabular}{|c|c|c|c|c|c|}
\hline & & $\begin{array}{c}\text { Levene } \\
\text { Statistic }\end{array}$ & df1 & df2 & Sig. \\
\hline \multirow[t]{4}{*}{ Hasil Belajar Siswa } & Based on Mean & 8,127 & 1 & 39 &, 007 \\
\hline & Based on Median & 4,104 & 1 & 39 &, 050 \\
\hline & $\begin{array}{l}\text { Based on Median and } \\
\text { with adjusted df }\end{array}$ & 4,104 & 1 & 34,863 & ,051 \\
\hline & $\begin{array}{l}\text { Based on trimmed } \\
\text { mean }\end{array}$ & 7,955 & 1 & 39 & ,008 \\
\hline
\end{tabular}

Tabel 5. Uji Homogenitas Setelah Perlakuan

\begin{tabular}{llrrrr}
\hline & $\begin{array}{c}\text { Levene } \\
\text { Statistic }\end{array}$ & \multicolumn{1}{c}{ df1 } & \multicolumn{1}{c}{ df2 } & \multicolumn{1}{c}{ Sig. } \\
\hline Hasil Belajar Siswa &, 063 & 1 & 39 &, 802 \\
& $\begin{array}{l}\text { Based on Mean } \\
\text { Based on Median }\end{array}$ &, 061 & 1 & 39 &, 806 \\
$\begin{array}{l}\text { Based on Median and } \\
\text { with adjusted df }\end{array}$ &, 061 & 1 & 38,633 &, 806 \\
$\begin{array}{l}\text { Based on trimmed } \\
\text { mean }\end{array}$ &, 069 & 1 & 39 &, 794 \\
\hline
\end{tabular}

Setelah melakukan uji persyaratan yang telah dilakukan dapat diketahui bahwa data distribusi normal dantidak homogen. Setelah itu dilakukan analisis uji T menggunakan independent sample T test. Uji T bertujuan untuk mengetahui ada tidaknya perbedaan efektivitas antara kedua kelompok eksperimen terhadap kemampuan berpikir kritis siswa. Hasil analisis uji $\mathrm{T}$ disajikan dalam bentuk Tabel 6.

Berdasarkan data Tabel 6, hasil uji T menggunakan independent sample $T$ test menunjukkan hasil bahwa $t_{\text {hitung }}$ sebesar 2,114 dengan signifikasi pada kolom Sig(2-tailed) sebesar 0,041. Perbedaan rata-rata dari kelompok mean diference sebesar 5,382. $\mathrm{T}_{\text {tabel }}$ yang diperoleh dari data diatas adalah 2,020. 


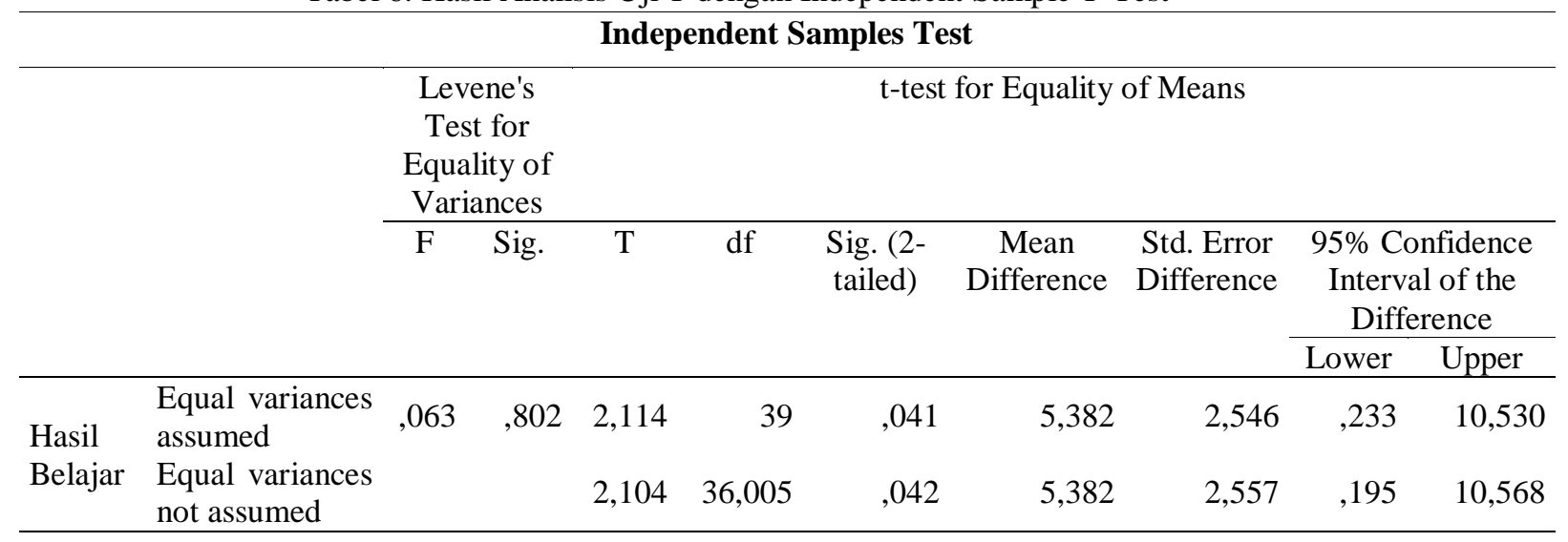

Setelah melakukan analisis uji independent sample T test pada Tabel 6, selanjutnya untuk uji hipotesis penelitian. Langkah-langkah dalam pengujian hipotesis bertujuan untuk menentukan apakah hipotesis diterima atau ditolak.

$\mathrm{H}_{0}$ : Tidak terdapat perbedaan yang signifikan antara penggunaan model Problem

Based Learning dan Problem Solving terhadap kemampuan berpikir kritis dalam mata pelajaran Matematika siswa kelas V.

$\mathrm{H}_{\mathrm{a}}$ : Terdapat perbedaan yang signifikan antara penggunaan model Problem Based Learning dan Problem Solving terhadap kemampuan berpikir kritis dalam mata pelajaran Matematika siswa kelas V.

Kriteria pengambilan keputusan:

1. Menggunakan koefisien Sig. Dengan ketentuan :

a. Jika nilai sig. Hitung (probabilitas) $<0,05 \mathrm{H}_{0}$ ditolak

b. Jika nilai sig. Hitung (probabilitas) $>0,05 \mathrm{H}_{0}$ diterima

2. Menggunakan koefisien t Hitung dengan ketentuan :

a. Jika koefisien t Hitung $>\mathrm{t}$ tabel maka $\mathrm{H}_{0}$ ditolak

b. Jika koefisien $\mathrm{t}$ Hitung $>\mathrm{t}$ tabel maka $\mathrm{H}_{0}$ diterima

Sesuai dengan kriteria pengujian hipotesis, bahwa nilai signifikasinya menunjukkan $0,041<0,05$ sehingga $\mathrm{H}_{0}$ ditolak. Oleh sebab itu hasil uji hipotesis menyatakan terdapat perbedaan efektivitas model pembelajaran Problem Based Learning dan Problem Solving terhadp kemampuan berpikir kritis dalam mata pelajaran Matematika siswa kelas V.

Berdasarkan uji beda rata-rata posttest dapat dilihat bahwa kemampuan berpikir kritis matematis siswa kelompok eksperimen 1 lebih tinggi dubandingkan 
dengan kelompok eksperimen 2. Hal ini menunjukkan bahwa perlakuan yang dilakukan pada kelompok eksperimen 1 lebih efektif dibandingkan dengan perlakukan kelompok eksperimen 2. Uji normalitas Gain digunakan untuk mengetahui seberapa kuat keefektifandari penerapan kedua model pembelajaran. Rumus yang digunakan dalam uji normalitas Gain yaitu rumus Hake yang dapat dilihat pada tabel berikut.

$$
N-\text { gain }=\frac{\text { Sposttest }- \text { Spretest }}{\text { Smax }- \text { Spretest }}
$$

Keterangan:

S posttest : Skor posttest

S pretest : Skor pretest

S max $\quad$ : Skor maksimum ideal

Tabel 7. Kategori Perolehan Skor N-Gain

\begin{tabular}{cc}
\hline Batasan & Kategori \\
\hline $\mathrm{g}>0,7$ & Tinggi \\
$0,3<\mathrm{g} \leq 0,7$ & Sedang \\
$\mathrm{g}<0,3$ & Rendah \\
\hline
\end{tabular}

Hasil uji normalitas gain kelas eksperimen 1 menunjukkan bahwa rata-rata kelas eksperimen 1 mengalami peningkatan sebesar 0,59 yang berarti N-Gain mengalami peningkatan kategori sedang. Sedangkan hasil uji normalitas gain kelas eksperimen 2 memiliki rata-rata 0,50 yang berarti $\mathrm{N}$-Gain juga mengalami peningkatan kategori sedang.

Berdasarkan hasil penelitian, model pembelajaran Problem Based Learning dan Problem Solving dapat meningkatkan kemampuan berpikir kritis siswa. Keberhasilan penelitian inididukung dengan meningkatnya hasil pretest ke posttest sehingga dapat diketahui terdadapat perbedaan yang signifikan ketika sesudah dilakukan penerapan menggunakan model Problem Based Learning dan sesudah dilakukan peneraran model Problem Solving. Dengan dilakukan analisis data menunjukkan hasil menggunakan model Problem Based Learning lebih tinggi dibandingkan dengan menggunakan model Problem Solving. 


\section{SIMPULAN}

Berdasarkan pembahasan yang telah diuraikan sebelumnya, maka dapat disimpulkan bahwa terdapat perbedaan kemampuan berpikir kritis siswa dari kelas eksperimen 1 yang menggunakan model Problem Based Learning dan kelas eksperimen 2 menggunakan model Problem Solving. Kedua model tersebut dapat meningkatkan kemampuan berpikir kritis matematis siswa dengan hasil uji $\mathrm{N}$ Gain untuk mengetahui keefektifannya. Hasil uji N-Gain menunjukkan kelas eksperimen 1 sebesar 0,59 dan kelas eksperimen 2 sebesar 0,50 sehingga dapat disimpulkan untuk meningkatkan kemampuan berpikir kritis matematis siswa lebih efektif jika menggunakan model Problem Based Learning.

\section{DAFTAR PUSTAKA}

Amir, T. (2009). Inovasi Pendidikan Melalui Problem Based Learning. Jakarta: Kencana Prenada Media Grup.

Andari, T. (2012). Efektifitas Pembelajaran Matematika Menggunakan Pendekatan Kontekstual Terhadap Prestasi Belajar Matematika ditinjau dari Kemampuan Awal Siswa Kelas V SD Se-Kecamatan Bangunrejo kabupaten Lampung Tengah. Jurnal Ilmiah Pendidikan Matematika, 1 (1).

Arifin, Z. (2012). Penelitian Pendidikan Metode dan Paradigma Baru . Bandung: Remaja Rosdakarya Offset.

Boendan, D. d. (2017). Efektivitas Model Pembelajaran Problem Based Learning Ditinjau Dari Kemampuan Pemecahan Masalah Dan Kepercayaan Diri Siswa Kelas VII SMP Negeri 1 Sanden Yogykarta. Jurnal Pendidikan Matematika, 6 (9).

Fadillah, A. (2016). Pengaruh Pembelajaran Problem Solving Terhadap Kemampuan Berpikir Kreatif Matematis Siswa. Jurnal Pendidikan Matematika, 2 (1).

Indarwati, D., Wahyudi, W., \& Ratu, N. (2014). PENINGKATAN KEMAMPUAN PEMECAHAN MASALAH MATEMATIKA MELALUI PENERAPAN PROBLEM BASED LEARNING UNTUK SISWA KELAS V SD. Satya Widya, 30(1), 17-27.

Mahmuzah, R. (2015). Peningkatan Kemampuan Berpikir Kritis Matematis Siswa SMP Melalui Pendekatan Problem Posing. Jurnal Peluang, 4 (1), 23025158 .

Sanjaya, W. (2013). PENELITIAN PENDIDIKAN Jenis,Metode dan Prosedur. Jakarta: Kencana Premada Media Group.

Slameto (2010). Belajar dan Faktor-Faktor yang Mempengaruhinya. Jakarta: PT. Rineka Cipta. 
Slameto (2015). Metodologi Penelitian \& Inovasi Pendidikan. Salatiga: Satya Wacana University Press.

Sugiono (2011). Metode Penelitian Pendidikan (Pendekatan Kuantitatif, Kualitatif, dan $R \& D)$ ). Bandung: Alfabeta.

Sugiyanto (2010). Model-model Pembelajaran Inovatif (Cetakan Ke-2).

Surakarta: Yuma Pressindo.

Sugiyono (2010). Metode Penelitian Kuantitatif \& RND. Bandung: Alfabeta.

Sugiyono, P. D. (2013). METODE PENELITIAN PENDIDIKAN (Pendekatan Kuantitatif, Kualitatif, dan $R \& D)$. Bandung: Alvabeta.

Sugiyono, P. (2013). METODE PENELITIAN PENDIDIKAN (Pendekatan Kuantitatif, Kualitatif, dan R\&D). Bandung: Alvabeta.

Suryosubroto, B. (2009). Proses Belajar Mengajar Di Sekolah. Jakarta: PT Rineka Cipta.

Wahyudi, A. I. (2018). Pengembangan Model Blended Learning Berbasis Proyek untuk Menunjang Kreatifitas Mahasiswa Merancang Pembelajaran Matematika Sekolah Dasar. JIPM (Jurnal Ilmiah Pendidikan Matematika), $6(2), 68-81$.

Wahyudi, Waluya, S. B., Rochmad, \& Suyitno, H. (2018). Assimilation and Accommodation Processes in Improving Mathematical Creative Thinking with Scaffolding According to Learning Style. In Journal of Physics: Conference Series(Vol. 1097). Institute of Physics Publishing. https://doi.org/10.1088/1742-6596/1097/1/012156

Yusi Hidjrawan, I. K. (2016). Efektivitas Model Pembelajaran Problem Solving Terhadap Keterampilan Berpikir Kritis dan Hasil Belajar Peserta Didik pada Materi Larutan Penyangga di SMA Negeri 7 Banda Aceh. Jurnal Pendidikan Sains Indonesia, 4 (2), 140-150.

Yusuf, O. L. (2017). Problem Solving Dalam Pembelajaran Matematika. UIN Raden Intan Lampung. 